\title{
Impact of Economic Downturn on Child Labor in Vietnam
}

\author{
Nguyen Thanh Huyen* \\ Vietnam National University, Vietnam
}

\begin{abstract}
The economic recession led to the economic downturn, loss of jobs and income, and the risk of falling back into the poverty of near-poor and poor households. This recession caused an increase in child labor. This study aimed to analyze the concept of child and child labor under a regulatory framework and assess how the economic downturn affects child labor in Vietnam. This study used analytical research methods through synthesis, comparison, and legal analysis, emphasizing literary research based on secondary research data. This study showed that the economic downturn increased the proportion of child labor because the parents and the family's breadwinner are unemployed or cut down on their income. Children were out of school to help household businesses or look for work for extra income. The economic downturn increased the number of children working in unsafe working conditions. It increased the risk of children being forced into illegal jobs prohibited and exposing children to labor to risk forced labor. It resulted in difficulties preventing and eliminating child labor, especially in a developing country like Vietnam, due to the high number of employees working in the informal sector, who were often unsupported by social security policies such as unemployment insurance and social insurance. This study suggested that the Government should establish policies to promote sustainable economic development and promulgate appropriate social security policies to promptly support workers and their families out of difficulties caused by job loss. Also, it should organize the effective implementation of regulations on eliminating child labor and raise social awareness in preventing and eliminating child labor.
\end{abstract}

KEYWORDS: Economic Downturn, Child Labor, COVID-19 Pandemic.

Copyright $\odot 2021$ by Author(s)

This work is licensed under a Creative Commons Attribution-ShareAlike 4.0 International License. All writings published in this journal are personal views of the authors and do not represent the views of this journal and the author's affiliated institutions.

HOW TO CITE:

Huyen, Nguyen Thanh, "Impact of Economic Downturn on Child Labor in Vietnam" (2021) 8:3 Lentera Hukum 447-470. DOI: <https://doi.org/ 10.19184/ejlh. v8i3.25506>.

Submitted: 16/07/2021 Reviewed: 08/09/2021 Revised: 12/11/2021 Accepted: 22/11/2021

* Corresponding author's e-mail: huyenluat1976@gmail.com 


\section{INTRODUCTION}

Socio-economic conditions and poverty are key factors to contribute to child labor. ${ }^{1}$ The economic downturn caused by the COVID-19 pandemic is considered the biggest catastrophe. It confronts the world since World War II, the most significant economic downturn since the Great Depression of $1930 .^{2}$ The economic downturn has affected all aspects of social life, including child labor which the international community, countries, and society are trying to eliminate because of its severe consequences for the younger generation.

There have been previous studies on child labor and its impact on economic recession and economic growth. First, the International Labor Organization (ILO) in 2013 showed that child labor is a vital part of a symptom of poverty; child labor is most pervasive in countries where income levels are lowest. ${ }^{3}$ This report affirmed child labor is not an isolated issue explained by poverty. Instead, the child labor phenomenon is the combined product of many factors that bridge traditional policy boundaries. ${ }^{4}$ Secondly, another research pointed out that household-level poverty is a crucial driver of child labor and some factors contributing to child labor, including economic vulnerability associated with poverty, risk in driving children to work, barriers to education, discriminatory social and cultural norms, poor enforcement of legislation and policies to protect children, and lack of decent work opportunities. ${ }^{5}$ Third, another study also concluded that widespread child employment dampers future economic

1 Sourav Mondal, et al., "Characteristics of Child Labour and Their Health Problems: Findings from Rural Community of India" (2016) 8:10 Health, online: <https://www.scirp.org/journal/paperinformation.aspx?paperid=68374>.

2 Nhật Minh, "World economy before the COVID-19 epidemic," online: <https:// tapchicongsan.org.vn/web/guest/the-gioi-van-de-su-kien/-/2018/820140/kinh-tethe-gioi-truoc-dich-benh-covid-19.aspx>.

3 International Labor Organization, World Report on Child Labor: Economic Vulnerability, Social Protection, and the Fight Against Child Labor (Geneva: International Labor Office, 2013) at 11-12.

$4 \quad$ Ibid at 13.

5 Paola Pereznieto, et al., "Eliminating Child Labor, Achieving Inclusive Economic Growth" (2016) World Vision UK and Overseas Development Institute, online: $<$ https://assets.worldvision.org.uk/files/2214/7801/5728/Child_labour_-_Economic_ Growth_report_-_Oct_2016.pdf> at 13-14. 
growth through its negative impact on child development and depresses current growth by reducing unskilled wages and discouraging the adoption of skill-intensive technologies. ${ }^{6}$ ILO and the United Nations Children's Fund (UNICEF) in 2020 reported that the COVID-19 pandemic increased economic insecurity, profoundly disrupted supply chains, and halted manufacturing. ${ }^{7}$ Tightening credit is constraining financial markets in many countries, and public budgets are straining to keep up. ${ }^{8}$ When these and other factors result in losses in household income, expectations that children contribute financially can intensify. More children could be forced into exploitative and hazardous jobs. ${ }^{9}$ In summary, these previous studies showed some impacts from many social factors on child labor, in which economic factors are emphasized.

However, they only focused on the consequences of economic recession, poverty, increased child labor, and labor laws for minor workers. They did not critically examine how poverty and economic recession affect child labor as well as ways to limit the impact of the economic downturn on child labor. This study aimed to critically examine the impact of the economic downturn on child labor, encompassing children dropping out of school to support the family economy and work in hazardous jobs, as well as work in unguaranteed conditions. They are at risk of doing the worst jobs prohibited by law and at risk of being forced into labor.

This study consists of two main discussions to deal with reflections on the legal basis of child labor. The first part analyzes the impact of economic recession on child labor by referring to the case in Vietnam. The second part provides alternatives to limit the negative impacts of the economic downturn on child labor. This study suggested preventing and eliminating child labor caused by the economic downturn in Vietnam.

6 Eric V Edmonds \& Caroline Theoharides, "Child Labor and Economic Development" in Handbook of Labor, Human Resources and Population Economics (New York, Springer, 2020) at 1.

7 International Labor Organization and United Nations Children's Fund, COVID-19 and Child Labor: A Time of Crisis, A Time to Act (New York: ILO and UNICEF, 2020) at 1.

8 Ibid.

$9 \quad$ Ibid. 


\section{METHODS}

This study used qualitative research methods based on the collection and analysis of data mainly from the 2018 National Child Labor Survey of Vietnam. It was conducted in conjunction with the 2018 Labor Force Survey by the General Statistics Office of Vietnam (GSO) in November and December 2018, with a sample size of 38,280 households nationwide in 2,552 enumeration areas. In addition, this research used the data from published papers. These data were analyzed or illustrated with charts to prove the statements in this study. Also, this study used analytical, synthetic, and comparative research methods, emphasizing literary research to assess the impact of the economic downturn on child labor in different aspects. Moreover, the legal analysis method was used to analyze shortcomings in policies and legal regulations to promote the economy to overcome the recession, as well as some rules of Vietnam to prevent and eliminate child labor.

\section{IMPACT OF ECONOMIC RECESSION ON CHILD LABOR IN VIETNAM}

The surveys on child labor showed that family financial conditions, poverty, and income pressures are still the fundamental reasons children participate in work and child labor. ${ }^{10}$ The economic downturn and the COVID-19 pandemic have had many implications on child labor.

\section{A. The Pandemic and Economic Recession's Impacts on Children's Study}

The pandemic and economic recession make children ineligible to study well, even leave school early to join the labor force to help support the family economy. The Ebola epidemic from 2014-2016 was a reason for the significant increase in child labor in West Africa. ${ }^{11}$ Large numbers of

${ }^{10}$ International Labor Organization \& General Statistics Office \& Ministry of Labor, Invalids and Social Affairs, Viet Nam National Child Labour Survey 2018 - Key Findings (Geneva: ILO, 2020) at 67.

${ }^{11}$ Iffat Idris, Impact of COVID-19 on Child Labour in South Asia (K4D Helpdesk Report 819) (Brighton: Institute of Development Studies, 2020) at 2. 
children were left vulnerable, and child labor (and child marriage) is influenced regions expanded. ${ }^{12}$ Children also reported accomplishing more family errands, like gathering kindling and getting water. ${ }^{13}$

In Vietnam, the COVID-19 pandemic has severely affected the whole society. As of December 2020, Vietnam had 32.1 million people aged 15, and they were affected. In the first quarter of 2021, the unemployed working-age was nearly 1.1 million, increasing 12,100 people compared to the first quarter of $2020 .{ }^{14}$ Unemployment and rotational leave mean no income or reduced income; all directly affect workers and their families. Vietnam had between 4.6 and 10.3 million workers affected by the pandemic in April 2020. ${ }^{15}$ They have to cut many types of spending, including spending on their children's education and learning. This pandemic has also affected nearly 23 million students, ${ }^{16}$ from pre-school to high school, impoverished children who are not eligible for online or television learning. During the implementation of social distancing, the number of children absent from school tends to increase mainly due to the difficulty of their families' economy. Then, they drop out of school to help support the family, especially children in highlands, deep-lying, remote, and economically disadvantaged areas. The high dropout rate (with over 10 students per year) mainly concentrates on ethnic groups such as Mong, Dao, Xodan, Ede, Cham, Khmer. ${ }^{17}$ It affects an individual's positions and

12 Edo Fernando, "Criminal Law Policy on the Protection of the Marriage of the Underage Children" (2020) 1:1 Indonesian Journal of Law and Society 75-100 at 76.

13 Iffat Idris, supra note 11.

14 TuoiTre Online, "More than 1 million people were unemployed and underemployed in the first quarter because of COVID-19," online: <https://tuoitre.vn/hon-1-trieu-nguoithat-nghiep-thieu-viec-lam-trong-quy-1-vi-covid-19-20210416103932254.html>.

15 UNICEF, "World Day Against Child Labour 2020: Viet Nam joins global campaign to confront the intensified risk of child labor resulting from COVID-19," online: $<$ https://www.unicef.org/vietnam/press-releases/world-day-against-child-labour2020-viet-nam-joins-global-campaign-confront>.

16 Giaoduc Vietnam, "Nearly 23 million students nationwide start the new school year 2020-2021," online: <https://giaoduc.net.vn/giao-duc-24h/gan-23-trieu-hoc-sinhca-nuoc-khai-giang-nam-hoc-moi-2020-2021-post212153.gd >.

17 Thanh Huyền (2020) "What is the solution to the problem of ethnic minority students dropping out of school?," online: <https://baodantoc.vn/giai-phap-nao-cho-van-nanhoc-sinh-dtts-bo-hoc.? 
pays in the future because each year of additional schooling prompts an 11 percent ascending later income for an individual on average. ${ }^{18}$ In particular, as of October 2020, children orphaned by the pandemic have reached 2,500 children. Ho Chi Minh City is the locality with the highest number of orphans with 1,584 children, Binh Duong has 233 children, Dong Nai has $121 .{ }^{19}$ As a result, these children are at risk of dropping out of school and will engage in labor for a living.

Due to the economic recession, the absence of children from school does not only help families reduce spending but also contributes to finding more income. Many families believe that children's participation in working helps them grow up faster. Child labor is mainly involved in economic activities in the informal economy. In the formal economy, there are still a few cases of child labor participating in working before reaching the age of majority, at least as required by law, or children working in heavy, hazardous, and dangerous conditions prohibited by law. According to ILO, instances of child labor under 15 were discovered. ${ }^{20}$ One deals with a teenager working for a catering service sub-contractor. Another involves two teenagers recruited as temporary sewing assistants four months short of their $15^{\text {th }}$ birthdays. ${ }^{21}$ Only $2 / 15$ of child labor continued to attend the Continuing Education program in the evening or weekend. ${ }^{22}$ From 2020, the implemented social distance in Vietnam has made it even more difficult to check and detect early acts of abuse and exploitation of child labor at production facilities.

18 Paola Pereznieto, et al.,, supra note 5. at 16.

19 Cong an Nhan Dan Online, "Proposal to support 2,500 orphans due to the death of their parents due to COVID-19," online: <https://cand.com.vn/Xa-hoi/de-xuat-ho-tro-2500-tre-mo-coi-do-cha-me-mat-vi-dich-covid-19-i632106/ "Đề xuất hỗ trợ 2.500 trẻ mồ côi do cha, mẹ mất vì dịch COVID-19>.

20 ILO \& IFC, Better Work: Annual Report 2019 An Industry And Compliance Review Vietnam (Geneva: Better Work, 2019) at 17.

21 Ibid.

22 NTT Thuy, et al., "Impact of COVID-19 on Child Labor Prevention in Industrial Construction Sector," online: <https://shapesea.com/wp-content/uploads/2021/05/ impact-of-covid-19-on-child-labor-prevention-in-industrial-construction-sectorthuy-huyen.pdf $>$. 


\begin{tabular}{lrrrrrrrr}
\hline \multirow{2}{*}{ Causes } & \multirow{2}{*}{ Total } & \multirow{2}{*}{ \% } & \multicolumn{2}{c}{ Sex (\%) } & \multicolumn{2}{c}{ Age group (\%) } \\
\cline { 5 - 9 } & & & & Male & Female & $\begin{array}{r}5-12 \\
\text { years }\end{array}$ & $\begin{array}{r}\text { 13-14 } \\
\text { years }\end{array}$ & $\begin{array}{r}\text { 15-17 } \\
\text { years }\end{array}$ \\
\hline Nationwide & $1,031,944$ & 100 & 100 & 100 & 100 & 100 & 100 \\
\hline Income generation for oneself & 95,956 & 9.3 & 9.8 & 8.5 & 3.9 & 3.6 & 14.6 \\
\hline Income generation for family & 213,319 & 20.7 & 21.9 & 18.9 & 10.2 & 24.8 & 25.5 \\
\hline $\begin{array}{l}\text { A desire to involve in household's } \\
\text { production and business }\end{array}$ & 281,651 & 27.3 & 27.4 & 27.1 & 37.6 & 27.8 & 20.9 \\
\hline Desire for apprenticeship & 32,549 & 3.2 & 4.2 & 1.7 & 0.0 & 0.4 & 6.0 \\
\hline Non-school attendance & 68,688 & 6.7 & 8.2 & 4.4 & 2.7 & 4.6 & 9.8 \\
\hline Others & 11,561 & 1.1 & 1.0 & 1.3 & 1.2 & 0.5 & 1.3 \\
\hline Not classified & 328,220 & 31.7 & 27.5 & 38.1 & 44.4 & 38.3 & 21.9 \\
\hline
\end{tabular}

Table 1: Causes for participation in economic activities by children in child labor ${ }^{23}$

According to the above table, up to $30 \%$ of children work to generate income for themselves and their families. The trend is most evident in older children in child labor (15-17 years), where almost 40.1 percent expressed that they worked to generate pay. 27.3 percent of them participate in labor to assist in the production and business process of households. While the economy is not the main reason, up to 30 percent of children are not deprived of the right to study. Children's participation in labor can earn money to serve their life, but it deprives the opportunity to work sustainably in the future because of being uneducated and untrained at a young age. In addition, the younger children start to work, the more significant the impact of work on learning loss. It is demonstrated to be especially the case for children under 13 years old, experiencing different adverse consequences beyond education, such as health and attitudes. Vietnamese data show that child labor prompts generous negative implications on school participation and accomplishment. Then, decreased generally cumulated profit in the mid to long haul. ${ }^{24}$

23 International Labor Organization \& General Statistics Office \& Ministry of Labor, Invalids and Social Affairs, supra note 9 at 34.

${ }^{24}$ Paola Pereznieto, et. al., supra note 5 at 17. 


\section{B. Economic Downturn as A Cause of Child Labor}

The economic downturn is also a cause for children to work in unsafe working conditions. More than 50 percent of children did not attend school due to working to help families earn extra income. ${ }^{25}$ They often have to work from 8 hours to 10 hours per day to help support their families. ${ }^{26}$ Due to the economic recession, children participating in labor work as employees or work with their families in unguaranteed conditions, such as working age, working time, rest time, employment, and hazardous workplace with dangerous elements.

\section{The age of child labor starting to work}

Due to the economic downturn or poverty, children often have to join the labor force at an early age to support the family economy or to earn their living. As indicated in the diagram below, there is 53.4 percent that begin to work at 12 years old or more. 10.3 percent began to work under 10 years old, and 3.5 percent began to work at 5-7 years old, which is exceptionally young to start working since it often adversely influences children's health.

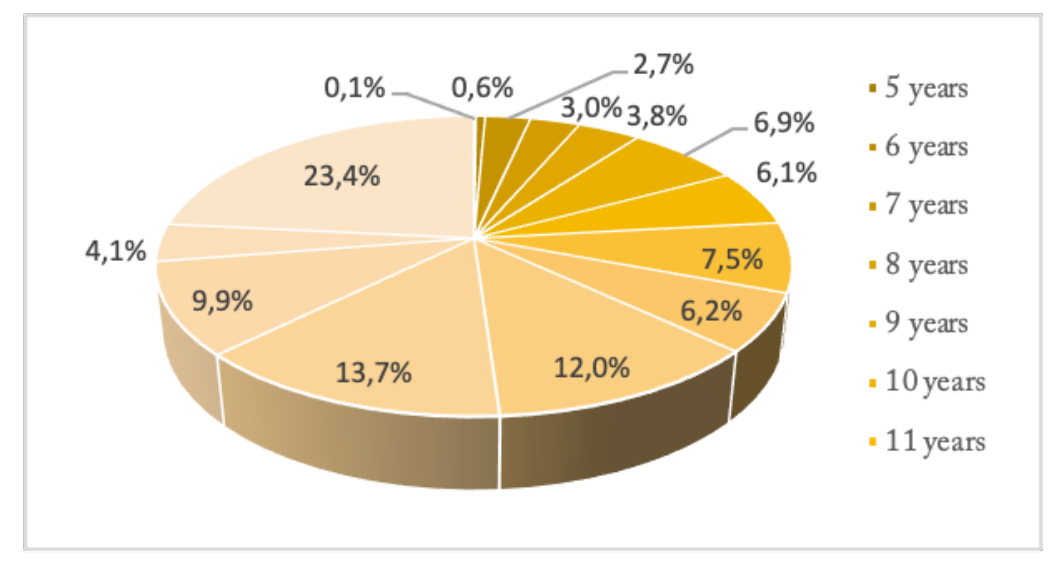

Chart 1: The age of child labor starting to work ${ }^{27}$

25 The Management and Sustainable Development Institute \& Save the Children Survey Results Report Young Voices in Vietnam (2020) at 13.

${ }^{26}$ Ibid.

${ }^{27}$ International Labor Organization \& General Statistics Office \& Ministry of Labor, Invalids and Social Affairs, supra note 9 at 40-41. 
2. The conditions of working time of child labor

Some children participating in work are not guaranteed the working time and rest time. According to the Labor Code of Vietnam 2019, the operating hours of people under 15 years old must not exceed 04 hours per day and 20 hours per week. The minor is not allowed to work overtime and work at night. ${ }^{28}$ Working hours of people from full 15 years old to fewer than 18 years old must not exceed 8 hours per day and 40 hours per week. ${ }^{29}$

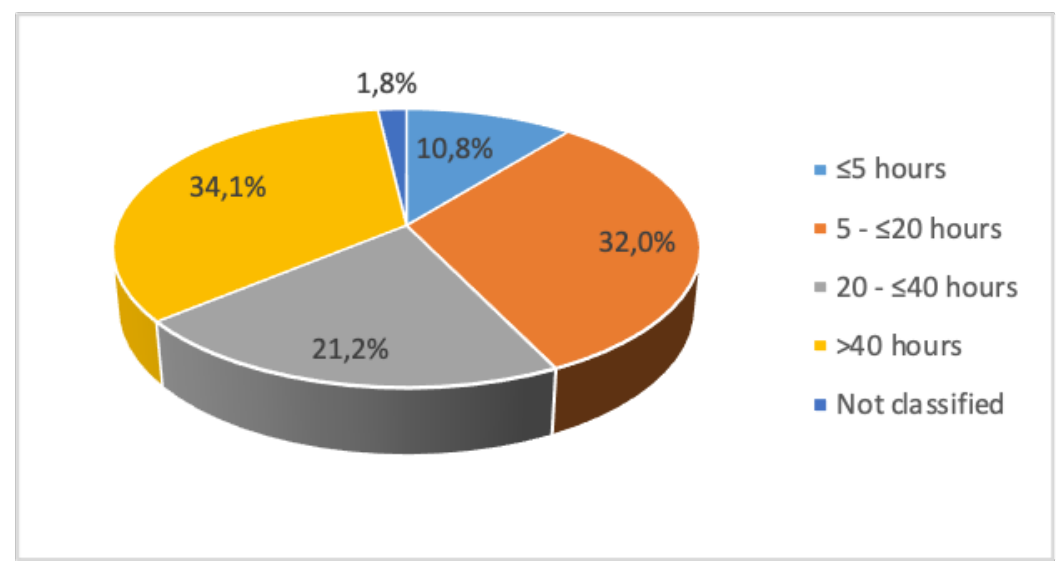

Chart 2: Child labor by working time per week ${ }^{30}$

According to the chart above, 34.1 percent of child labor had extended working hours 40 hours or more per week. It is in opposition to the Labor Code 2019 of Vietnam and adversely influences the health of most working children, particularly the young ones.

\section{Work and workplace of child labor}

According to the chart above, regarding the work that child labor does mainly in the agricultural sector, which attracts 62.2 percent of child labor, in the industry and construction, 18.3 percent of child laborers participate, and the service industry attracted 19.5 percent of child laborers to participate. With working location, children in child labor work in very assorted areas for certain primary places where these children often work,

28 Clause 1 Article 146 Labor Code of Vietnam 2019.

29 Clause 2 Article 146 Labor Code of Vietnam 2019.

30 International Labor Organization \& General Statistics Office \& Ministry of Labor, Invalids and Social Affairs, supra note 9 at 36. 
namely their house (24.7 percent); farms, fields, and gardens (12.1 percent); construction sites (12.2 percent); mobile workplaces (over 8 percent); shop/kiosk/restaurants (around 4.8 percent). ${ }^{31}$

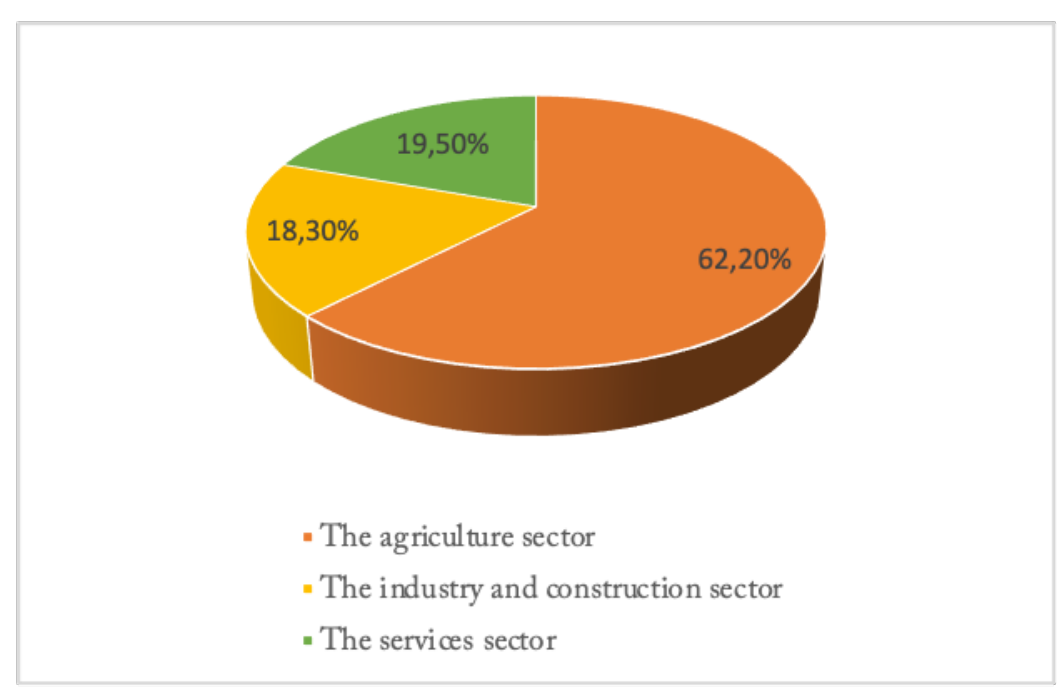

Chart 3: Child labor by sector of work ${ }^{32}$

In the past period, due to the COVID-19 pandemic, children had to stay home from school. Many families did not have a babysitter (especially kindergarten and primary school age). Their parents had to take their children to work (like selling goods at the market, working on the farm, or working in a small factory at home), both working and looking after them. Children do not participate in labor, but their safety is not guaranteed.

\section{Economic Downturn and Children's Engagement to Worst Jobs}

The economic downturn increases the risk that children are forced to engage in the worst jobs prohibited by law. In compliance with the provisions on prohibition and urgent action to eliminate the worst forms of child labor in Convention No. 182, 1999 of ILO, Viet Nam has issued a list of jobs and workplaces where it is strictly forbidden for minors to

31 Ibid at 35.

32 Ibid at 34. 
participate. ${ }^{33}$ In fact, according to Viet Nam National Child Labor Survey 2018 Key finding, nearly 10.5 percent of children in child labor had to lift heavy objects weighing 30 or more kilograms. It was almost 9.1 percent of them had to operate production machines and equipment during their working process. However, the majority of these children were adolescents, about 15-17 years old, and at this age, they are more physically mature and more mindful of labor safety at work. ${ }^{34}$

Children in child labor often worked in hazardous environments and working conditions to the working environment. The survey results in the table above indicate that 27.7 percent of these children were in touch with ashes, garbage, and exhaust at their workplace. 11.5 percent worked in environments that had high levels of vibration and strong movement. Nearly 11 percent of them were involved in work environments with extreme temperatures, and over 8 percent were in touch with chemical substances at work. Primarily, more than 3.2 percent of them worked on construction sites, and more than 3 percent worked in the underwater environment. These working environments were regularly considered hazardous for children. It affects children's health negatively, physical and mental health such as poor growth, malnutrition, higher incidence of infectious and system-specific diseases, behavioral and emotional disorders, and decreased coping efficacy, ${ }^{35}$ even affecting their lives. For example, an estimated 13.3 percent of these children have undergone skin or open wounds, dislocations, sprains, bruises (over 4 percent). ${ }^{36}$

33 Article 147 Labor Code 2019 and Appendix III and Appendix IV issued with Circular No. 09/2020/TT-BLDTBXH dated November 12, 2020, of the Minister of Labor, War Invalids, and Social Affairs.

34 International Labor Organization \& General Statistics Office \& Ministry of Labor, Invalids and Social Affairs, supra note 9 at 38.

35 Abdalla Ibrahim, et al., "Child Labor and Health: A Systematic Literature Review of the Impacts of Child Labor on Child's Health in Low and Middle-Income Countries" (2019) 41:1 Journal of Public Health 18-26.

36 International Labor Organization \& General Statistics Office \& Ministry of Labor, Invalids and Social Affairs, supra note 9 at 42. 
Working environment

Total $\%$

\begin{tabular}{lrr}
\hline Dust, rubbish, smoke & 286,253 & 27.7 \\
\hline Gases, flammable and explosive substances & 26,069 & 2.5 \\
\hline High level of vibration and strong movement & 119,363 & 11.5 \\
\hline Extreme temperatures & 111,927 & 10.8 \\
\hline Working underground/in caves/ tunnels & 3,097 & 0.3 \\
\hline Working in high places (over 3 meters) & 25,554 & 2.5 \\
\hline Working underwater (ponds, lakes) diving and offshore fishing & 33,373 & 3.2 \\
\hline Too dark and too narrow workplaces & 10,642 & 1.0 \\
\hline Contact with chemical substances (Pesticides, glue) & 82,860 & 8.0 \\
\hline Addictive substances (drug) & 749 & 0.1 \\
\hline Working on construction sites & 33,702 & 3.3 \\
\hline Working in smithies, medical metal casting workshops & 6,765 & 0.7 \\
\hline Working in production workshops or running businesses on & 4,024 & 0.4 \\
beverage/cigarettes & & \\
\hline Others & 10,266 & 1.0
\end{tabular}

Table 2: Child labor by the working environment ${ }^{37}$

The economic recession increased child labor doing hazardous jobs for a living. Many children have to accept working even in conditions that adversely affect their health to get a job in difficult times. According to the result of the research, out of 519,805 children doing heavy, hazardous, and dangerous work, up to $47 \%$ are child labor receiving wages and salaries; ${ }^{38}$ $43 \%$ are household child labor. ${ }^{39}$ Although children who do these jobs are mainly in the age group from 15 to 17 years old with relatively good physical strength, the number is worth considering (519.805 children), accounting for 50.4 percent of the total number of child labor and account for 2.7 percent of the country's population of children between 5 and 17

\footnotetext{
37 Ibid at 37.

38 Ibid at 46.

39 Ibid.
} 
years old. ${ }^{40} 40.6$ percent of child laborers do heavy, hazardous, and dangerous work with 40 working hours or more per week. ${ }^{41}$

This data is worth pondering and needs an appropriate way to reduce child laborers doing heavy, hazardous, and dangerous work in the household. For example, the Program on Prevention and Elimination of Child Labor in Agriculture and Fishing in a Raft Village (Ma Da Commune, Vinh Cuu District, Dong Nai Province) have helped at least 250 children under 18 years of age laborers or at risk of heavy and hazardous, dangerous labor in the fields of agriculture and fishing and these children's families are the beneficiaries of direct support from the program to help them to prevent, protect, or removed from heavy, hazardous, or dangerous work. ${ }^{42}$ Besides, due to the difficulties caused by the economic recession, it is also difficult for production facilities to invest in machinery and improve working conditions, especially for small and micro-production units.

\section{Economic Downturn and the Risk of Forced Labor}

The economic downturn makes children involved in work will face the risk of forced labor. According to statistics, for every 1000 children in the world, 4.4 children are victims of modern slavery, ${ }^{43}$ and more than 1 million victims of forced sexual exploitation-21 percent of all victims-were children under $18 .^{44}$ In Vietnam, there are no official survey data on forced labor against children. However, in reality, many children work to earn their living in remote places without the protection of their parents. Some children are forced to work at the request of their employers, are not agreed and guaranteed in terms of wages, working hours, rest time, or are physically and mentally abused.

40 Ibid at 45.

${ }^{41}$ Ibid at 51.

${ }^{42}$ Ministry of Labour, Invalids and Social Affairs - International Labor Organization ILO (2013) "Prevention and Elimination of Child Labor in Agriculture and Fishing in a Raft Village - Potential Model Document" Capacity in Ma Da Commune, Vinh Cuu District, Dong Nai Province" at 4.

43 ILO \& Walk Free Foundation, Global estimates of modern slavery: forced labor and forced marriage (Geneva: ILO, 2017) at 24.

${ }^{44}$ Ibid at 40. 
From the above analysis, the economic downturn substantially impacts the increase in child labor. In other studies, the experts also prove how putting resources into eradicating child labor can add to inclusive economic development, advance global prosperity, and handle extreme poverty. ${ }^{45}$ Thus, the relationship between the economy and child labor is dialectical, the economic recession increases child labor, and the elimination of child labor is a way to help the economy grow. For the cancelation of child labor to promote human resources improvement, a vital driver of economic development, ${ }^{46}$ and the abolition of child labor to promote decent work. ${ }^{47}$ In addition, to participate more deeply in global trade, Vietnamese businesses need to ensure that their supply chains do not use child labor. ${ }^{48}$

\section{ALTERNATIVES TO LIMIT NEGATIVE IMPACTS OF THE ECONOMIC DOWNTURN ON CHILD LABOR}

Disadvantaged people facing difficulties due to economic decline should be supported on time. It is to minimize negative impacts on children in general and child labor in particular. Hoop and Rosati showed that cash transfers to helpless families lessen child labor. ${ }^{49}$ These transfers particularly significant in assisting families with adapting to economic shocks, by referring to an experience of Mexico and Zambia. ${ }^{50}$ In Vietnam, the ways to directly support poor children to go to school through supporting books, school supplies, and expenses; household livelihood development, and

45 Paola Pereznieto, et al., supra note 5 at 16.

46 Ibid.

47 Ibid at 19.

48 DTQ Trang \& NTL Anh, Preventing and Eliminating Child Labor in Vietnam's Businesses in the Context of COVID-19 Epidemic, online <https://shapesea.com/wpcontent/uploads/2021/05/preventing-and-eliminating-child-labor-in-vietnamtrang_lan-anh.pdf>.

49 Jacobus De Hoop \& Furio C. Rosati, “Cash Transfers and Child Labor" (2014) 29:2 World Bank Research Observer 202-234.

50 Alain de Javry, et al., "Can Conditional Cash Transfer Programs Serve as Safety Nets in Keeping Children at School and from Working When Exposed to Shocks?" (2006) 79:2 Journal of Development Economics 349-373. Solomon Asfaw, et al., "Cash Transfer Programmes, Weather Shocks and Household Welfare: Evidence from A Randomised Experiment in Zambia" (2017) 9:4 Journal of Development Effectiveness 419-442. 
vocational training for parents of benefits children have also been effectively implemented in the rafting ${ }^{51}$ and handicraft villages. ${ }^{52}$ In the Indonesian context, it also works in spite of several critiques on its effective measures to improve school access. ${ }^{53}$

In Vietnam, social security policies like paying unemployment insurance, supporting workers who are briefly suspended from work, subsidizing poor people, and the individuals who have lost their pay because of the impact of the COVID-19 pandemic-implementation of social distancing-was promptly and effectively implemented. The number of unemployed decided to receive unemployment benefits from the social insurance agency to organize payment in 2020 was 1.019 million people, an increase of 141.290 people (16.1 percent) compared to 2019. ${ }^{54}$ The amount of unemployment insurance payment was 16.219 billion VND, an increase of 4.043 billion VND (33.2 percent) over the same period in $2019 .{ }^{55}$ The increase in the number of recepients receiving unemployment benefits is caused by the suspension of business or bankruptcy due to pandemic and economic recession.

Workers in the informal sector need more attention as this group accounts for a large proportion, is vulnerable and suffers the most. This group is outside the scope of benefits of the current policy. The Vietnamese Government has implemented a support package of 62 trillion VND (the

51 Ministry of Labour, Invalids and Social Affairs - International Labor Organization (2013), "Prevention and Elimination of Child Labor in Agriculture and Fishing Sectors in a Raft Village. Documenting Potential Modeling in Ma Da Commune, Vinh Cuu District, Dong Nai Province" International Program on Elimination of Child Labor (IPEC), ILO Office in Vietnam. - Hanoi, 2013 at 21.

52 Ministry of Labour, Invalids and Social Affairs - International Labor Organization (2013), "Prevention and Elimination of Child Labor in Traditional Craft Villages Wood and Stone Crafts. Documenting the Potential Model in Hien Giang Commune, Thuong Tin District, Hanoi City". International Program on the Elimination of Child Labor (IPEC), ILO Viet Nam Office. - Hanoi, 2013 at 10.

53 Muhammad Bahrul Ulum \& Dina Tsalist Wildana, "Promoting the Right to Education through A Card: A Paradox of Indonesia's Educational Policy?" (2019) 4:1 Journal of Indonesian Legal Studies 143-160 at 150.

54 Vietnam Social Insurance (2021), Report on the results of leadership and management in 2020 and directions and tasks in 2021, January 11, 2021.

55 Ibid. 
first time), ${ }^{56}$ for both employees and self-employed people across the country, so it is difficult to determine the beneficiaries. It is the reason that this support is difficult to quickly and promptly reach those who need help. While the Government timely supports employees and self-employed people to overcome difficulties due to the impact of COVID-19, it will limit children's participation in labor. Thus, the Government should assign local authorities to identify the self-employed to receive timely support to solve this situation. When workers affected by the economic downturn receive timely help, it will help their families' lives be less disturbed, help them have the opportunity to find suitable jobs, adapt to new situations, and not fall into unnecessary tragedies. This policy is the basis for reducing child labor in Vietnam. In July 2021, with the recent outbreak of COVID19 , the Government of Vietnam enacted a social security support package with 26 trillion VND (the second time) ${ }^{57}$ and overcome procedural limitations so that people in need can receive support in time.

The Government and business should issue and implement comprehensive solutions to promote economic recovery. They are essential to minimize the negative impacts of the economic downturn, particularly against child labor. First, the Government needs to accelerate the implementation of public investment to help the economy recover from the COVID-19 recession and create more direct jobs in the short term and other indirect jobs in a long time. The Fiscal Monitor of the International Monetary Fund (IMF) estimates that a 1 percent GDP increase in public investment in advanced economies and developing markets can move GDP up by 2.7 percent and private investment by 10 percent. Above all, they, directly and indirectly, make somewhere in the range of 20 and 33 million jobs. ${ }^{58}$ In Vietnam, the General Statistics Office (GSO) estimates that for every one

56 The Government Resolution No 42/2020/NQ-CP, April 09, 2020, on measures to support people affected by the COVID-19 epidemic.

57 The Vietnam Government Resolution No 68/2021/NQ-CP, July 01, 2021, on policies to support COVID-19-hit employees and employers.

58 International Monetary Fund, Fiscal Monitor: Policies for the Recovery (International Monetary Fund, 2020) at x. 
percentage point increase in public investment, GDP will rise by 0.06 percentage points. ${ }^{59}$

In addition, the Government also needs to issue policies to help businesses overcome the economic downturn; some guidelines have been published and implemented by the Vietnamese Government, such as (1) reducing $15 \%$ of the land rent to be paid in 2020 for enterprises, organizations, households, and individuals that are directly leased land by the State according to Decision and/or contract of competent State agency in the form of annual rent payment, who has to stop production and business due to the effect of Covid-19 pandemic; ${ }^{60}$ (2) exempting the guarantee charge arising in 2020 for government-guaranteed loans to aviation businesses with outstanding loans until December 31, 2019;'1 (3) reducing by $50 \%$ the price takeoff, landing ships flying and operating services prices fly away, come for flights flying inland from March to the end of September 2020;62 (4) reducing $2 \%$ interest rates for direct loans, indirect loans for small and medium enterprises from the Small and Medium Enterprises Development Fund; ${ }^{63}$ (5) reducing 30\% of the corporate income tax payable for 2020 for small and micro enterprises to support in the context of the COVID-19 pandemic. ${ }^{64}$ However, according to experts, reducing tax and land rent does not help businesses overcome difficulties. ${ }^{65}$ The Government needs a comprehensive solution to support enterprises to recover from the influence of COVID-19. When the economy is restored, and more workers have jobs and incomes, their lives and that of their families will be improved,

59 Nhan Dan, "Public investment is a major driver of Vietnam's economic growth in 2020," online: <https://en.nhandan.vn/business/tem/9450202-public-investment-is-majordriver-of-vietnam\%E2\%80\%99s-economic-growth-in-2020.html>.

60 Resolution No 84/2020/NQ-CP of the Government on May 29, 2020, Regarding the tasks and solutions to continue to remove difficulties in production and business, accelerate the disbursement of public investment and ensure social order and safety in the context of Covid-19 pandemic.

61 Ibid.

62 Ibid.

63 Ibid.

64 Ibid.

65 National Economic University (NEU) \& Japan International Cooperation Agency, Assessment of Policies to Cope with COVID-19 and Recommendation NEU-JICA Report (Hanoi, Vietnam: NEU \& JICA, 2020) at 4. 
and it will have a positive impact on the reduction and elimination of child labor.

Nevertheless, perfect legal regulations prevent and eliminate child labor. In addition to specific legal provisions aimed at recovering the economy and helping businesses overcome the recession caused by the COVID-19 pandemic, the law also needs to clearly define the content of the concept of "child labor" to the prevention and elimination of child labor is made easier in practice. It is important to reiterate that child labor is the use of children to work contrary to the provisions of the law. Many experts believe that it is appropriate for Vietnamese law to stipulate that children are under 16 years old. ${ }^{66}$ However, in Vietnam, children aged 16 to under 18 suffer from many disadvantages and unfortunate influences, such as being exploited, trafficked, kidnapped, abused, neglected, and abandoned. Meanwhile, Vietnam's current policies and legal regulations on the protection, care, and education of children mainly focus on the group of under 16 years old without due attention to the group of children - young people from 16 to under 18 years old. ${ }^{67}$ Therefore, the author recommends that Vietnamese law stipulate that children should be understood as persons under the age of 18 as regulated in the United Nations Convention on the Rights of the Child to protect children better, including the prevention and elimination of child labor.

For jobs children can participate in, Vietnam's labor law only stipulates a list of light jobs that people from full 13 to fewer than 15 years old can do. ${ }^{68}$ According to Vietnam Labor Code 2019, employers may not recruit and employ persons under 13 years, except for arts and physical training and sports. Those jobs are regarded as not harmful to these persons'

${ }^{66}$ LTK Van \& VC Giao, Legal Age of Children Under Vietnamese Law Debates and Perspectives (Hanoi, Vietnam, 2019).

67 Bảo Yến, "It is necessary to improve the law on the protection of children from full 16 to under 18 years old according to the international convention on the rights of the child," online: <https://quochoi.vn/UserControls/Publishing/News/BinhLuan/pFormPrint .aspx?UrlListProcess=/content/tintuc/Lists/News\&ItemID=44693>.

68 Appendix II, Circular No. 09/2020/TT-BLDTBXH on November 12, 2020, of The Ministry of Labor, Invalids and Social Affairs, Detailing and guiding the implementation of some articles of the Labor Code on minor workers. 
physical, intellectual, and personality development. They shall get the consent of specialized agencies in charge of labor under provincial-level People's Committees. ${ }^{69}$ In addition, the labor law also stipulates a list of jobs that harm the physical, intellectual, and personality development of minors; ${ }^{70}$ the list of workplaces that harm the physical, mental, and personality development of minors. ${ }^{71}$ Therefore, any entity that employs minors to do prohibited jobs or work in such prohibited places will be handled by the law. However, the regulations on handling administrative violations for violations against the rules on minor labor only sanction the employer-the entity that hires or employs the employee to do the job for themselves under the agreement) to commit this violation. ${ }^{72}$

The criminal handling of crimes against regulations on employees under 16 years old is also difficult. It has been a prevalent challenge in many developing countries, which includes Indonesia. The Indonesian Government included child labor as a criminal act for employers, but its implementation remains arduous to enforce. ${ }^{73}$ One of the cases for unlawful handling is that the violation has been sanctioned for administrative violations of this behavior. When children do prohibited jobs and workplaces for their own families, Decree 28/2020/ND-CP cannot be applied to administrative sanctions and also faces difficulties when dealing with children's criminal prosecution in this case. Besides, Decree No. $143 / 2013 / \mathrm{NĐ}-\mathrm{CP}$ stipulates that anyone who forces a child subject to social protection (children under 16 years old with no source of support) to do hard, hazardous, dangerous labor shall be subject to a fine of from

69 Clause 3, Article 145 Vietnam Labor Code 2019.

70 Appendix III, Circular No. 09/2020/TT-BLDTBXH on November 12, 2020, of The Ministry of Labor, Invalids and Social Affairs, Detailing and guiding the implementation of several articles of the Labor Code on minor workers.

71 Ibid.

72 Article 28, Decree No. 28/2020/ND-CP, March 01, 2020, of Government, Providing penalties for administrative violations in the fields of labor, social insurance, and overseas workforce supply under contract.

73 Vience Ratna Multiwijaya, "Perlindungan dan Sanksi Pidana bagi Pemberi Kerja Anak" (2018) 1:1 Hukum Pidana dan Pembangunan Hukum 6 at 5. 
$5,000,000 \mathrm{VND}$ to $10,000,000 \mathrm{VND} .{ }^{74}$ Thus, this regulation only protects children subject to social protection, not all children. The omission in the two Decrees mentioned above has led to using child labor for the family or business household has not yet been prevented. To prevent and eliminate child labor, these legal obstacles need to be amended.

Finally, raising awareness in preventing and eliminating child labor. There is a need to strengthen propaganda to raise awareness of people and businesses about the prohibition of using child labor, especially using child labor to do terrible jobs. Families, schools, and employers need to be acutely aware of the long-term harmful effects of child labor on children and their families and society as a whole.

\section{CONCLUSION}

The economic recession impacts all socio-economic aspects, especially an increase in child labor. The economic downturn is why children have to leave school early to earn a living or join the labor force to help support the family economy. When participating in child labor, they face many risks such as not ensuring working hours, not ensuring occupational safety and workplace hygiene, or being forced to work. The study suggests different solutions to prevent and eliminate child labor. It is necessary to have appropriate welfare policies to support workers and their families through the difficulties of the economic downturn. At the same time, the guidelines to restore and promote economic development need to be effectively built and implemented because it will create more jobs and better working conditions and income for workers. In addition, legal policies on the prevention and abolition of child labor also need to be completed and effectively implemented. These solutions are a sustainable basis for children to study and not work to earn a living.

${ }^{74}$ Article 5, Point c, Clause 2 Decree No. 143/2013/NĐ-CP October 29, 2013, of Government, Regulations on sanctioning administrative violations in social protection and children's and the safety of children. 


\section{ACKNOWLEDGMENTS}

None.

\section{COMPETING INTEREST}

The author declared that she has no competing interests.

\section{REFERENCES}

Asfaw, Solomon, et al., "Cash Transfer Programmes, Weather Shocks and Household Welfare: Evidence from A Randomised Experiment in Zambia" (2017) 9:4 Journal of Development Effectiveness 419-442.

Bảo Yến, "It is necessary to improve the law on the protection of children from full 16 to under 18 years old according to the international convention on the rights of the child," online: <https:/quochoi.vn/UserControls/ Publishing/News/BinhLuan/pFormPrint.aspx?UrlListProcess=/ content/tintuc/Lists/News\&ItemID=44693>.

Cong an Nhan Dan Online, "Proposal to support 2,500 orphans due to the death of their parents due to COVID-19," online: <https://cand.com. vn/Xa-hoi/de-xuat-ho-tro-2-500-tre-mo-coi-do-cha-me-mat-vidich-covid-19-i632106/ "Đề xuất hỗ trợ 2.500 trẻ mồ côi do cha, mẹ mất vì dịch COVID-19>.

Giaoduc Vietnam, "Nearly 23 million students nationwide start the new school year 2020-2021," online: <https:/giaoduc.net.vn/giao-duc-24h/gan23-trieu-hoc-sinh-ca-nuoc-khai-giang-nam-hoc-moi-2020-2021post212153.gd >.

Hoop, Jacobus De \& Furio C. Rosati, "Cash Transfers and Child Labor" (2014) 29:2 World Bank Research Observer 202-234.

Ibrahim, Abdalla, et al., "Child Labor and Health: A Systematic Literature Review of the Impacts of Child Labor on Child's Health in Low and Middle-Income Countries"(2019) 41:1 Journal of Public Health 18-26. 
Idris, Iffat, Impact of COVID-19 on Child Labour in South Asia (K4D Helpdesk Report 819) (Brighton: Institute of Development Studies, 2020).

ILO \& Walk Free Foundation, Global estimates of modern slavery: forced labor and forced marriage (Geneva: ILO, 2017).

International Labor Organization and United Nations Children's Fund, COVID-19 and Child Labor: A Time of Crisis, A Time to Act (New York: ILO and UNICEF, 2020).

International Labor Organization \& General Statistics Office \& Ministry of Labor, Invalids and Social Affairs, Viet Nam National Child Labour Survey 2018 - Key Findings (Geneva: ILO, 2020).

International Labor Organization, World Report on Child Labor: Economic Vulnerability, Social Protection, and the Fight Against Child Labor (Geneva: International Labor Office, 2013).

International Monetary Fund, Fiscal Monitor: Policies for the Recovery (International Monetary Fund, 2020).

Javry, Alain de, et al., "Can Conditional Cash Transfer Programs Serve as Safety Nets in Keeping Children at School and from Working When Exposed to Shocks?" (2006) 79:2 Journal of Development Economics 349-373.

Ministry of Labour, Invalids and Social Affairs - International Labor Organization (2013), "Prevention and Elimination of Child Labor in Agriculture and Fishing Sectors in a Raft Village. Documenting Potential Modeling in Ma Da Commune, Vinh Cuu District, Dong Nai Province" International Program on Elimination of Child Labor (IPEC), ILO Office in Vietnam. - Hanoi, 2013.

Ministry of Labour, Invalids and Social Affairs - International Labor Organization (2013), "Prevention and Elimination of Child Labor in Traditional Craft Villages Wood and Stone Crafts. Documenting the Potential Model in Hien Giang Commune, Thuong Tin District, Hanoi City". International Program on the Elimination of Child Labor (IPEC), ILO Viet Nam Office. - Hanoi, 2013. 
Multiwijaya, Vience Ratna, "Perlindungan dan Sanksi Pidana bagi Pemberi Kerja Anak" (2018) 1:1 Hukum Pidana dan Pembangunan Hukum 6.

Minh, Nhật, "World economy before the COVID-19 epidemic," online: $<$ https://tapchicongsan.org.vn/web/guest/the-gioi-van-de-su-kien/-/ 2018/820140/kinh-te-the-gioi-truoc-dich-benh-covid-19.aspx>.

Ministry of Labour, Invalids and Social Affairs - International Labor Organization, "Prevention and Elimination of Child Labor in Agriculture and Fishing in a Raft Village - Potential Model Document" Capacity in Ma Da Commune, Vinh Cuu District, Dong Nai Province," (2013).

Mondal, Sourav et al., "Characteristics of Child Labour and Their Health Problems: Findings from Rural Community of India” (2016) 8:10 Health, online: <https://www.scirp.org/journal/paperinformation.aspx ?paperid $=68374>$.

National Economic University (NEU) \& Japan International Cooperation Agency, Assessment of Policies to Cope with COVID-19 and Recommendation NEU-JICA Report (Hanoi, Vietnam: NEU \& JICA, 2020).

Nhan Dan, "Public investment is a major driver of Vietnam's economic growth in 2020," online: <https://en.nhandan.vn/business/tem/9450202public-investment-is-major-driver-of-vietnam\%E2\%80\%99seconomic-growth-in-2020.html>.

Pereznieto, Paola, et al., "Eliminating Child Labor, Achieving Inclusive Economic Growth" (2016) World Vision UK and Overseas Development Institute, online: <https://assets.worldvision.org.uk/ files/2214/7801/5728/Child_labour_-_Economic_Growth_report_-_ Oct_2016.pdf>.

Thanh Huyền, "What is the solution to the problem of ethnic minority students dropping out of school?," online: <https://baodantoc.vn/giai-phap-naocho-van-nan-hoc-sinh-dtts-bo-hoc>.

The Management and Sustainable Development Institute \& Save the Children Survey Results Report Young Voices in Vietnam (2020). 
Thuy, NTT, et al., "Impact of COVID-19 on Child Labor Prevention in Industrial - Construction Sector," online: <https://shapesea.com/wpcontent/uploads/2021/05/impact-of-covid-19-on-child-labor-prevent ion-in-industrial-construction-sector-thuy-huyen.pdf>.

TuoiTre Online, "More than 1 million people were unemployed and underemployed in the first quarter because of COVID-19," online: $<$ https://tuoitre.vn/hon-1-trieu-nguoi-that-nghiep-thieu-viec-lamtrong-quy-1-vi-covid-19-20210416103932254.html>.

Ulum, Muhammad Bahrul \& Dina Tsalist Wildana, "Promoting the Right to Education through A Card: A Paradox of Indonesia's Educational Policy?” (2019) 4:1 Journal of Indonesian Legal Studies 143-160.

UNICEF, "World Day Against Child Labour 2020: Viet Nam joins global campaign to confront the intensified risk of child labor resulting from COVID-19," online: <https://www.unicef.org/vietnam/press-releases/ world-day-against-child-labour-2020-viet-nam-joins-globalcampaign-confront>.

Van, LTK \& VC Giao, Legal Age of Children Under Vietnamese Law Debates and Perspectives (Hanoi, Vietnam, 2019).

Vietnam Social Insurance (2021), Report on the results of leadership and management in 2020 and directions and tasks in 2021, January 11, 2021.

V. Edmonds, Eric \& Caroline Theoharides, "Child Labor and Economic Development" in Handbook of Labor, Human Resources and Population Economics (New York, Springer, 2020). 